\title{
PENGGUNAAN QAWA'ID FIQHIYYAH DALAM PUTUSAN HAKIM DI PENGADILAN AGAMA MEDAN
}

\author{
Dedi Mahruzani Nur Lubis \\ dedimahruzaninurlubis@gmail.com \\ Pascasarjana Universitas Medan Area
}

\begin{abstract}
Abstrak
This article discusses the extent of the use of Qawaid Fiqhiyyah in the Medan District Court Judgment. Qawaid Fiqhiyyah will look its function when someone or a mujtahid even a judge in court when facing problems of Islamic law. One of the official government agencies that always faces cases and problems of Islamic law is the Religious Court. The Religious Courts in resolving disputes under their jurisdiction desperately need the qawäidh fiqhiyyah. The qawäidh fiqhiyyah to be referred by a Judge of the Religious Courts in their decisions will assist them in resolving the cases at hand. In its legal considerations, the judge will normatively mention the qawaidh fiqhiyyah as a reference in deciding a case. There are three decisions that are examined in this article about the extent of the use of fiqh rules in a Judge's decision in the Medan Religious Court.
\end{abstract}

Kata kunci: Judge's decision, Religious Court, Qawaid Fiqhiyyah

\section{A. Pendahuluan}

Sebagai salah satu disiplin ilmu Qawaid fiqhiyyah tidak berdiri sendiri dalam tema dan kajiannya. Sebagai derifasi dari fikih atau hukum Islam, qawaid fiqhiyyah merupakan simpul-simpul umum dari beberapa permasalahan hukum Islam yang dapat digunakan oleh kalangan awam maupun fuqaha dalam mencari solusi permasalahan hukum yang muncul di tengah masyarakat dalam pelbagai tema baik ibadah, muamalah, maupun isu-isu hukum Islam kontemporer. ${ }^{1}$

Qawaid Fiqhiyyah akan tampak fungsinya pada saat seseorang atau seorang mujtahid bahkan seorang hakim di pengadilan ketika menghadapi problematika hukum Islam. Problematika tersebut akan mengantarkan seorang mujtahid dan hakim kepada satu kesimpulan hukum yang itu sangat berarti bagi kepentingan umat Islam, biasanya para ulama mujtahid menghimpun dan mengumpulkan segala permasalahan hukum yang berada dan ditempatkan pada satu kaidah fikih. Apabila permasalahan tersebut sesuai dengan kaidah fikih yang bersifat kulli (universal) maka seorang mujtahid akan menemukan hukum terhadap problematika tersebut.

${ }^{1}$ Syamsul Hilal, Qawā'id Fiqhiyyah Furu'iyyah Sebagai Sumber Hukum Islam, Al-‘Adalah, Jurnal, Volume : 11, Nomor : 2 (Juli 2013), h. 141. 
Problematika yang dinamis, terlebih bersifat kasuistis merupakan wujud perkembangan komplesitas peradaban manusia. Islam secara subyektif, terlebih pendapat tokoh Islam secara fanatik-primordialis-subyektif turut andil dalam menyelesaikan beberapa kasus dengan perangkat operasional tertentu seperti Qawaid Fiqhiyyah. ${ }^{2}$

Qawaid fiqhiyyah merupakan landasan umum dalam pemikiran dan perilaku sosial memberikan panduan bagi masyarakat untuk melakukan interaksi dengan sesamanya. Panduan yang diberikan menyangkut beberapa aspek kehidupan seperti hukum, ekonomi, sosial, politik dan kenegaraan, budaya, dan sebagainya sampai pada masalah pernikahan ${ }^{3}$ dan juga tentang gugat-cerai.

Dengan menguasai kaidah-kaidah fikih kita mengetahui keterkaitan berbagai masalah dalam fikih, sebab kaidah fikih tempat kumpulan permasalah fikih, dan bijaksana menggunakan fikih di ruang dan waktu yang berbeda untuk kasus, keadaan, dan adat kebiasaan yang berlainan. Lebih moderat di dalam menyikapi permasalahan ekonomi, politik, sosial, budaya dan lebih mudah di dalam menyelsaikan permasalahan yang terus datang silih berganti dengan bersandar kepada kemaslahatan, keadilan, kerahmatan dan hikmah Problematika yang dinamis, terlebih bersifat yang terkandung di dalam fikih ${ }^{4}$. kasuistis merupakan wujud perkembangan komplesitas peradaban manusia. ${ }^{5}$

Menurut Ade Dedi Rohayana dalam bukunya Ilmu Qawaid Fiqhiyyah mengatakan bahwa Kaidah fiqih mempunyai fungsi mengklarifikasi terhadap permasalahan furu' dan menjadikannya menjadi beberapa bagian dan tiap-tiap bagian itu merupakan kumpulan dari permasalahan yang sama. Dengan berpegang pada kaidah ini, akan dirasa lebih mudah dalam istimbat hukum bagi suatu masalah. ${ }^{6}$ Begitu besar jasa ilmu Qawaid Fiqhiyyah terhadap penyelesaian kasuskasus yang berkaitan dengan hukum Islam, maka melalui kaidah fikih ini yang bersifat universal memberikan kesempatan dan peluang bagi siapa saja yang ingin mendalami fikih agar mempelajari, meneliti dan menulis tentang Qawaid Fiqhiyyah akan mengantarkannya lebih mudah untuk memahami fikih tanpa memerlukan waktu yang relatif lama.

Setidaknya upaya melakukan ijtihad terhadap masalah kekinian selain dengan menggunakan dua sumber utama yaitu al Quran dan hadits yang bersifat umum (tidak spesifik) juga bisa dengan dengan menggunakan kaidah fiqhiyyah yang sudah mapan yang telah dirumuskan oleh ahli fikih. ${ }^{7}$ Di dalam fatwa MUI

${ }^{2}$ Teguh Luhuringbudi dan Achmad Yani, Qawā'id Fiqhiyyah Terhadap Perbedaan Pendapat Dalam Fiqih (Kasus Hukuman Tindak Pidana Korupsi), Al Izzah: Jurnal Hasil-Hasil PenelitianISSN: 1978-9726 (p); 2541-0717 (e) Volume : 13, Nomor : 1 (Mei, 2018), h. 94.

${ }^{3}$ Masyhudi Muqorobin, Qawā'id Fiqhiyyah Sebagai Landasan Perilaku Ekonomi Umat Islam: Suatu Kajian Teoritik, Jurnal Ekonomi dan Studi Pembangunan Volume : 8, Nomor : 2, (Oktober 2007), h. 207.

${ }^{4}$ H. A. Djazuli, Kaidah-Kaidah Fikih (Jakarta : Kencana, 2011), h. 1.

${ }^{5}$ Teguh Luhuringbudi dan Achmad Yani, Op.Cit

${ }^{6}$ Lathifah Munawaroh, Penggunaan Kaidah Fiqhiyyah "Al-KhurūjMin Al-KhilāfMustahab"

Terkait Bab Ibadah Dalam Kitab I'ānat AlThālibīn, Nuansa : Jurnal Volume : 14, Nomor : 1 (Januari-Juni 2017), h. 8.

${ }^{7}$ Hammam, Urgensi Kaidah Fiqhiyyah Dalam Perumusan Hukum dan Implementasinya Dalam Fatwa DSN-MUI, Et-Tijarie: Jurnal Volume : 4, Nomor : 1 (Januari, 2017), h. 51 
juga, Qawaidh fiqhiyyah dijadikan salah satu landasan dalil dalam mengeluarkan fatwa Hukum. ${ }^{8}$

Salah satu instansi resmi pemerintah yang selalu menghadapi kasus serta problematika hukum Islam adalah Pengadilan Agama, Pengadilan Agama dalam menyelesaikan sengketa yang menjadi wewenang PA sangat membut uhkan kaidah fikih, kaidah fikih yang akan dirujuk oleh seorang Hakim Pengadilan Agama dalam put usannya akan membant unya dalam menyelesaikan kasus-kasus yang dihadapi. Berdasarkan survey penulis dari putusan Hakim Pengadilan Agama Kota Medan, para hakim biasanya merujuk kaidah fikih dalam putusan pada bagian Pertimbangan Hukum, dalam pertimbangan hukum ini, hakim secara normatif akan menyebutkan kaidah fikih yang menjadi rujukan dalam memutuskan perkara.

Untuk itu dalam makalah ini, penulis akan membahas hasil survey penggunaan qawaid fiqhiyyah di Pengadilan Agama Kota Medan, dengan mengambil tiga putusan sebagai hasil survey yaitu Putusan Pengadilan Agama Medan Nomor 2192/Pdt.G/2019/PA.Mdn dan Nomor 2337/Pdt.G/2019/PA.Mdn serta Putusan Pengadilan Agama Medan sebelum ada UU No. 7 Tahun 1989 Tentang Peradilan Agama Nomor 457/PTS/1988/PA.MDN. Selanjutnya penulis akan menganalisis penggunaan kaidah fikih tersebut.

\section{B. Survey Putusan Pengadilan Agama Medan Nomor 2192/Pdt.G/2019/PA.Mdn dan Nomor 2337/Pdt.G/2019/PA.Mdn serta Putusan Pengadilan Agama Medan sebelum berlakunya UU No. 7 Tahun 1989 Tentang Peradilan Agama Nomor 457/PTS/1988/PA.MDN}

Dalam pembahasan ini penulis akan menguraikan satu demi satu dari tiga perkara yang menjadi objek penelitian dalam makalah ini, yang diawali dari posita yaitu bagian yang berisi dalil yang menggambarkan adanya hubungan yang menjadi dasar atau uraian dari suatu tuntutan. Untuk mengajukan suatu tuntutan, seseorang harus menguraikan dulu alasan-alasan atau dalil sehingga ia bisa mengajukan tuntutan kemudian penulis akan langsung kepada Pertimbangan Hukum, dalam putusan pengadilan agama, kaidah fikih akan muncul jadi rujukan hakim dalam putusan tepatnya dalam Pertimbangan Hukum, sedangkan Petitum tidak penulis cantumkan dalam makalah ini karena kedua putusan ini sudah in craht/sudah mengikat. :

1. Perkara Nomor 2192/Pdt.G/2019/PA.Mdn

Perkara ini merupakan perkara cerai gugat seorang wanita umur 29 tahun, agama Islam, warganegara Indonesia, Pendidikan SLTA, Pekerjaan Pegawai Swasta, tempat tinggal di Jalan Xxxxxxxxx Kelurahan Xxxxxxxx, Kecamatan Medan Labuhan, Kota Medan, selanjutnya disebut sebagai Penggugat. Seorang umur 30 tahun, Agama Islam, Warganegara Indonesia, Pendidikan SLTP, Pekerjaan Wiraswasta, tempat tinggal di Jalan Xxxxxxxx Dusun Xxxx Desa Xxxxxxxx, Kecamatan Hamparan Perak, Kabupaten Deli Serdang, selanjutnya disebut Tergugat. Perceraian mereka terjadi karena mantan suami adalah sosok seseorang pecandu narkoba, hal ini dapat diketahui dari posita yaitu : Bahwa dalil

\footnotetext{
${ }^{8}$ Untuk mendapatkan keterangan tentang hal ini dapat dibaca dalam tulisan Heri Firmansyah, “Qawaidh Fiqhiyyah Dalam Fatwa Majelis Ulama Indonesia”, Al-Qadha: Vol.6, No.2, Juli 2019.
} 
Penggugat sebagai alasan utama menggugat cerai dari Tergugat adalah mengenai masalah hubungan Penggugat dengan Tergugat sebagai suami isteri terhitung sejak awal pernikahan sekitar bulan September 2014 sampai dengan saat ini telah berada dalam kondisi berselisih dan bertengkar secara terus menerus disebabkan karena :

A. Tergugat suka mengkonsumsi Narkoba sejenis shabu-shabu;

B. Tergugat tidak bertanggung jawab memberikan nafkah yang layak dalam memenuhi kebutuhan dan biaya rumah tangga Penggugat dan Tergugat, selalu memaksa Penggugat untuk mencari pinjaman kepada tetangga disekitar tempat tinggal;

C. Penggugat melihat bahwa Tergugat suka bermain perempuan, dan suka marah-marah bahkan menyia-nyiakan Penggugat;

D. Tergugat suka berbohong dan tidak jujur dengan Penggugat, malas kerja, dan tidak memperdulikan Penggugat. Sampai saat ini Tergugat tidak pernah lagi menafkahi Tergugat baik lahir maupun batin,

Selanjutnya dalam Pertimbangan Hukum, Hakim menyebutkan :

Menimbang, bahwa kondisi rumah tangga Penggugat dengan Tergugat sebagaimana yang dipertimbangkan di atas tidak lagi mungkin untuk mewujudkan tujuan perkawinan sehingga mempertahankan rumah tangga Penggugat dan Tergugat justru akan menimbulkan mafsadah bagi kedua belah pihak, sedangkan perceraian juga menghilangkan kemaslahatan yang tentu juga mafsadah bagi kedua pihak dan keluarga Penggugat dan Tergugat, namun oleh karena berhadapan dua mafsadah maka harus dipilih dengan melakukan mafsadah yang lebih ringan akibatnya, hal ini sesuai dengan qaedah fiqh yang berbunyi:

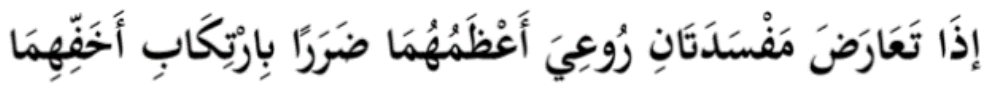

"Apabila berhadapan dua mafsadah dihindari mafsadah yang paling besar kemudratannya dengan melakukan yang lebih ringan mafsadahnya. (Asbahwa annazair, halaman 161);" ringan kemudarat an yang diterima Penggugat dan Tergugat, dibandingkan dengan mempertahankan rumah tangga Penggugat dengan Tergugat.

2. Perkara Nomor 2337/Pdt.G/2019/PA.Mdn

Perkara ini merupakan perkara cerai gugat seorang wanita Sakinah Zahra Binti Sujani, NIK 1271205609920001, lahir di Medan tanggal 16 September 1992, umur 27 tahun, agama Islam, pendidikan terakhir Strata I, pekerjaan Karyawan Swasta, tempat tinggal di Jalan Wiroto No. 15, Kelurahan Perintis, Kec. Medan Timur, Kota Medan, sebagai Penggugat. Seorang pria Geubrie Rizky Bin Muhammad Susatyo, S.H, umur 27 tahun, agama Islam, pendidikan terakhir Strata I, pekerjaan Tidak Bekerja, tempat tinggal di Jalan Panglima Denai (Penginapan Amplas/ Rumah Buk Nona), Kelurahan Amplas, Kecamatan Medan Amplas, Kota Medan, sebagai Tergugat;. Perceraian mereka terjadi karena mantan suami tidak memberikan nafkah rumah tangga, hal ini dapat diketahui dari posita yaitu : Bahwa pada awalnya rumah tangga Penggugat dan Tergugat rukun dan damai hanya berjalan selama sebulan, setelah itu timbullah permasalahan-permasalahan 
yang membuat ketidak harmonisan dalam rumah tangga Penggugat dan Tergugat terjadi sampai saat ini, yang hal ini penyebabnya antara lain adalah dikarenakan:

A. Bahwa antara Penggugat dengan Tergugat sering berselisih faham dan pendapat yang mana masalah yang awalnya kecil menjadi besar sehingga terjadilah pertengkaran antara Penggugat dan Tergugat, dan tak jarang setiap terjadi pertengkaran Tergugat berkata-kata kasar, sehingga hal tersebut sangat menyakitkan hati Penggugat;-

B. Bahwa Tergugat dari awal menikah tidak pernah memberikan nafkah kepada Penggugat sampai dengan sekarang, sehingga Penggugat merasa tidak mendapatkan haknya sebagai seorang istri;-

C. Bahwa Tergugat tergolong laki-laki yang tidak bertanggung jawab, hal mana Tergugat tidak mau bekerja mencari nafkah untuk memenuhi kebutuhan rumah tangga dan hanya mengharapkan bantuan dari orang tua Penggugat maupun orang tua Tergugat sehingga sudah tidak ada kecocokan lagi antara Penggugat dengan Tergugat;-

D. Bahwa Tergugat mengingkari janji yang diucapkannya sewaktu sebelum menikah yakni akan memberikan isi kamar seperti tempat tidur, lemari hias namun sampai sekarang janji tersebut tidak dipenuhi oleh Tergugat;Selanjutnya dalam Pertimbangan Hukum, Hakim menyebutkan :

Menimbang, bahwa kondisi rumah tangga Penggugat dan Tergugat sebagaimana yang dipertimbangkan di atas tidak lagi mungkin untuk mewujudkan tujuan perkawinan sehingga mempertahankan rumah tangga Penggugat dan Tergugat justru akan menimbulkan mafsadah bagi kedua belah pihak, sedangkan perceraian juga menghilangkan kemaslahat an yang tentu juga mafsadah bagi kedua pihak dan keluarga Penggugat dan Tergugat, namun oleh karena berhadapan dua mafsadah maka harus dipilih dengan melakukan mafsadah yang lebih ringan akibatnya, hal ini sesuai dengan qaedah fiqh yang berbunyi:

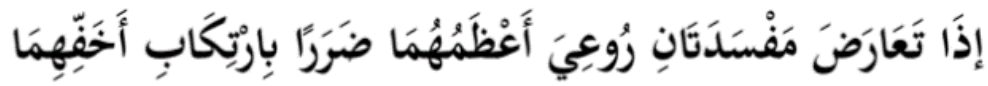

"Apabila berhadapan dua mafsadah dihindari mafsadah yang paling besar kemudratannya dengan melakukan yang lebih ringan mafsadahnya. (Asbahwa annazair, halaman 161);"

kemudaratan yang diterıma Penggugat dan lergugat, dibandıngkan dengan mempertahankan rumah tangga Penggugat dan Tergugat;

3. Perkara Nomor 457/PTS/1988/PA.MDN sebelum berlakunya UU No. 7 Tahun 1989 Tentang Peradilan Agama

Perkara ini merupakan perkara gugatan Tha'liq Thalaq antara seorang wanita Paini Binti Rajiman, umur 33 tahun, pekerjaan Ibu Rumah Tangga, alamat Jln : Garu-II-B No. 41/Lingkungan-III, Kelurahan Harjo Sari-I,Kec. Medan Johor, Kotamadya Medan, sebagai Penggugat. Lawan Seorang pria Yatiman Bin Surodinomo, umur 38 tahun, pekerjaan Wiraswasta, alamat d/a M. Jamil, Jln. Garu-II-B No.12/Lingkungan-III, Kelurahan Harjo Sari, Kecamatan Medan Johor, Kotamadya Medan, sebagai Tergugat;. Perceraian mereka terjadi karena mantan 
suami tidak memberikan nafkah rumah tangga, hal ini dapat diketahui dari posita yaitu :

A. Bahwa pada bulan Agustus 1987, Tergugat telah pergi meninggalkan Penggugat tanpa seizin dan sepengetahuan Penggugat, serta tanpa suatu sebab apapun dan baru pada bulan Juli 1988 Penggugat mengetahui bahwa Tergugat berada di Medan.

B. Bahwa sejak Tergugat pergi meninggalkan Penggugat, Tergugat tidak pernah memberi nafkah serta tidak pernah mengurusi Penggugat lagi.

C. Bahwa atas sikap dan perbuatan Tergugat tersebut Penggugat tidak rela, oleh karena itu Penggugat menggugat cerai dari Tergugat dengan alasan karena Tergugat telah melanggar sighot Thaliq Thalaq model A2 yang diucapkan Tergugat sewaktu menikah dahulu, berdasarkan alasan tersebut di atas Penggugat bermohon agar Majelis Hakim dapat menerima gugatan Penggugat dan menyatakan jatuhnya Thalaq satu Khuli dari Tergugat atas diri Penggugat dengan iwadl Rp. 50,- (lima puluh rupiah).

Selanjutnya dalam Pertimbangan Hukum, Hakim menyebutkan :

Menimbang, bahwa Tergugat telah melanggar sighot Thaliq Thalaq model A2 No. 1, 2 dan 4, oleh karena itu Majelis Hakim berkesimpulan bahwa gugat an Penggugat telah dapat diterima, sehingga telah dapat dinyatakan jatuhnya Thalaq 1 (satu) Khuli dari Tergugat at as diri Penggugat dengan iwadl Rp. 50,- (lima puluh rupiah), sehingga dengan dalil dari Kitab "Syarhut Tahrir" Juz-II, halaman 289, yang berbunyi sebagai berikut:

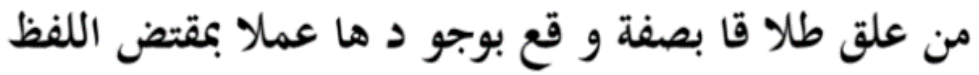

Artinya " Barang siapa yang menggantungkan Thalaqnya dengan suatu sifat, maka jatuhlah Thalaq tersebut dengan terwujudnya sifat dimaksud, semata-mata memandang kepada zahirnya lafaz Tha'liq Thalaq yang diucapkannya”.

D. Analisis Putusan Pengadilan Agama Medan Nomor 2192/Pdt.G/2019/PA.Mdn dan Nomor 2337/Pdt.G/2019/PA.Mdn serta Putusan Pengadilan Agama Medan sebelum berlakunya UU No. 7 Tahun 1989 Tentang Peradilan Agama Nomor 457/PTS/1988/PA.MDN

Pengadilan menyimpulkan bahwa suami isteri yang hendak bercerai sudah tidak dapat didamaikan dan jika perceraian lebih maslahat dibandingkan mempertahankan rumah tangganya maka perceraian pun akan diputuskan. ${ }^{9}$ Bahwa dengan terjadinya perceraian maka putuslah tali perkawinan suami dan isteri karena tidak adanya kecocokan sehingga tidak dapat diteruskan lagi dalam ikatan

${ }^{9}$ Suhaila Zulkifli, Putusnya Perkawinan Akibat Suami Menikah Tanpa Izin Dari Istri, Jurnal Hukum Kaidah Media Komunikasi dan Informasi Hukum dan Masyarakat Volume :18, Nomor : 3, h. 20 
Perkawinan keduanya, jadi perceraian merupakan pemutus hubungan suami dan isteri serta menghilangkan pula hak dan kewajiban suami dan isteri. ${ }^{10}$

Dalam menganalisis tiga putusan di atas, penulis akan membuatnya secara sistematis melalui penomoran sub bagian pembahasan agar analisis semakin mudah dipahami.

1. Pengutipan kaidah fikih hanya membatasi pada kaidah yang mengandung darar (bahaya/kerusakan)

Salah satu kaidah yang sering muncul dalam pertimbangan hakim memutuskan perkara cerai gugat adalah kaidah ${ }^{11}$ :

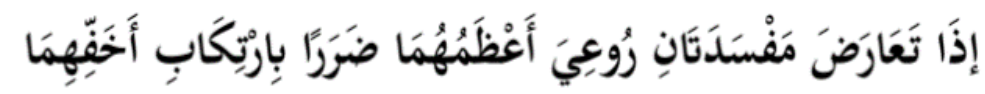

"Apabila berhadapan dua mafsadah dihindari mafsadah yang paling besar kemudratannya dengan melakukan yang lebih ringan mafsadahnya. (Asbahwa annazair, halaman 161);"

Menurut pendapat penulis kaidah fikih di atas "Apabila berhadapan dua mafsadah dihindari mafsadah yang paling besar kemudratannya dengan melakukan yang lebih ringan mafsadahnya" ditinjau dalam ruang lingkup hukum pidana umum kaidah ini sesuai maknanya dengan asas in dubio proreo "jika ada keraguraguan mengenai sesuatu hal haruslah diputuskan hal-hal yang menguntungkan terdakwa".

Yang kedua adalah kaidah fikih :

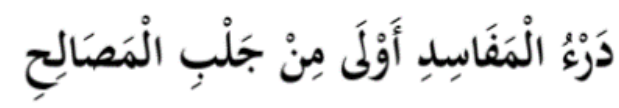

"menolak kerusakan lebih utama dari pada memilih kemaslahatan"

berhadapan dua mafsadah dihindari mafsadah yang paling besar kemudratannya dengan melakukan yang lebih ringan mafsadahnya" dalam putusan Pengadilan Agama disebabkan Hakim dalam memut uskan perkara mengetahui dan memahami kasusnya dengan menggunakan prinsip penalaran. Melihat dari sisi kemaslahatannya dan menghindari kemafsadatannya. Mafsadatnya dalam perkara ini adalah keburukan sebab sering terjadi selisih paham yang berujung pada percekcokan antara Penggugat dan Tergugat sehingga jalan ditempuh untuk kasus ini adalah perceraian ${ }^{12}$.

\footnotetext{
${ }^{10}$ Rusydi Ali Muhammad dan Yulmina, Multi Alasan Cerai Gugat: Tinjauan Fikih terhadap Cerai Gugat Perkara Nomor:0138/Pdt.G/2015/MS.Bna pada Mahkamah Syar'iyah Banda Aceh, Samarah: Jurnal Hukum Keluarga dan Hukum IslamVolume : 3 Nomor : 1. (Januari-Juni 2019), h. 36.

${ }^{11}$ Jalaluddin al-Suyuti, al-Asybah wan Nazair (Beirut Dar Kutub Ilmiyah, 1990), h. 87.

${ }^{12}$ Muhammad Arham, Kaidah Hukum Islam Dalam Pertimbangan Hukum Putusan Hakim (Yogyakarta : Makasar Press, 2007), h. 100.
} 
Kedua kaidah di atas merupakan kaidah fikih ada di kitab al-Asybah wan Nazair karangan imam Suyuti. Kaidah ini sebenarnya cabang dari kaidah dasar yang keempat yaitu :

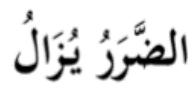

"Kemudharatan (bahaya/kerusakan) itu harus dihilangkan/dihindari)"

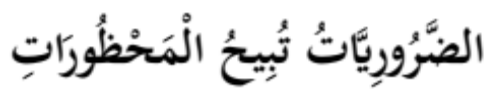

"kemudaratan membolehkan melakukan perbuatan yang dilarang"

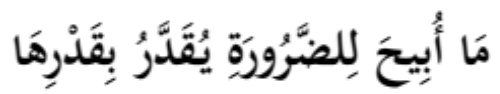

"suatu perbuatan yang dibolehkan karena mudarat harus ditolak (dihilangkan) sekedarnya saja"

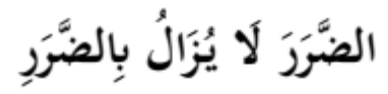

"kemudaratan tidak dapat dihilangkan dengan kemudaratan lagi"

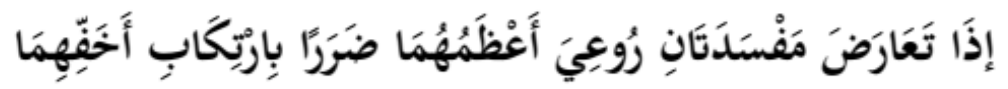

"Apabila berhadapan dua mafsadah dihindari mafsadah yang paling besar kemudratannya dengan melakukan yang lebih ringan mafsadahnya.

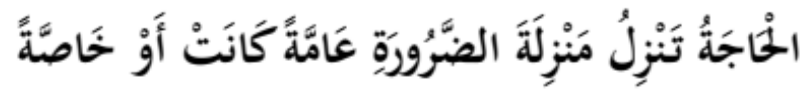

"Kedudukan kebutuhan itu kedudukan menempati darurat baik umum maupun khusus".

Pengutipan kaidah "Apabila berhadapan dua mafsadah dihindari mafsadah yang paling besar kemudratannya dengan melakukan yang lebih ringan mafsadahnya" apakah sesuai terhadap masalah atau perkara yang akan diputuskan perlu kehati-hatian dalam menerapkan kaidah.

Kehati-hatian dalam menggunakan kaidah ini diperlukan agar antara masalah yang akan dipecahkan dengan kaidah yang digunakan bisa tepat (pas). Sebab, antara masalah hukum yang dihadapi dengan kaidah fikih yang digunakan seperti kunci dan anak kuncinya. Artinya, harus pasangannya, tidak kebesaran dan tidak kekecilan, agar pintu bisa dibuka ${ }^{14}$.

Oleh karena itu, masalah yang dihadapi harus diteliti dahulu, setidaknya dalam lima aspek, yaitu: (1) ruang lingkup masalah yang dihadapi. Apakah masalah tersebut dalam bidang ibadah, munakahat, muamalah, jinayah, siyasah,

${ }^{13}$ Ibid, h. 83.

${ }^{14}$ H. A. Djazuli, Kaidah-Kaidah Fikih (Jakarta : Kencana 2011), h. 183. 
atau peradilan, atau menyangkut keseluruhan bidang tersebut; (2) apakah masalah yang dihadapi tersebut substansinya perubahan hukum atau bukan; (3) apakah masalah tersebut berhubungan dengan masalah prioritas karena adanya benturan atau pertentangan kepentingan sehingga diperlukan pilihan-pilihan mana yang akan diambil; (4) apakah masalah tersebut ruang lingkupnya sangat kecil yang hanya berhubungan dengan bab-bab tertentu dari bidang-bidang hukum islam sehinggah cukup digunakan al-qawaid al-tafshiliyah atau dhabith atau mulhaqnya; dan (5) hubungan antara masalah yang dipecahkan tersebut dengan teori teori fikih dalam arti teori materi fikih .Misalnya,apakah masalah tersebut berhubungan dengan teori teori fikih tentang akad (transaksi) atau tentang kepemilikan ,tentang subjek hukum baik pribadi (syakhshiyah) atau badan hukum (syakhshiyah hukumiyah) tentang hak-hak dan lain-lain ${ }^{15}$.

Sering terjadi orang menggunakan kaidah yang ruang lingkupnya besar untuk masalah yang kecil.Memang masalah kecil pasti masuk dalam kaidah fikih yang ruang lingkup nya besar. Tetapi lebih tepat apabila untuk masalah-masalah yang kecil selain ruang lingkup yang besar juga disertakan kaidah fikih yang ruang lingkupnya kecil.

Dalam perkara cerai gugat ini, jika ditinjau dari lima aspek kehati-hatian dalam penerapan kaidah fikih maka masalah ini masuk dalam bab fikih masalah munakahat (pernikahan) yang didalamnya terdapat perceraian. Sepanjang penelusuran penulis terhadap kitab al-Asybah wan Nazir contoh perkara atau kasus hukum islam dari kaidah :

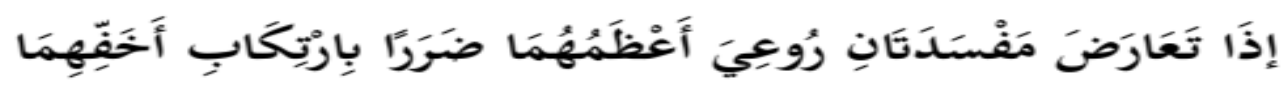

"Apabila berhadapan dua mafsadah dihindari mafsadah yang paling besar kemudratannya dengan melakukan yang lebih ringan mafsadahnya secara rinci menurut Imam Suyuti tidak mencontohkan perkara perceraian yang ada diantaranya adalah ${ }^{16}$ :

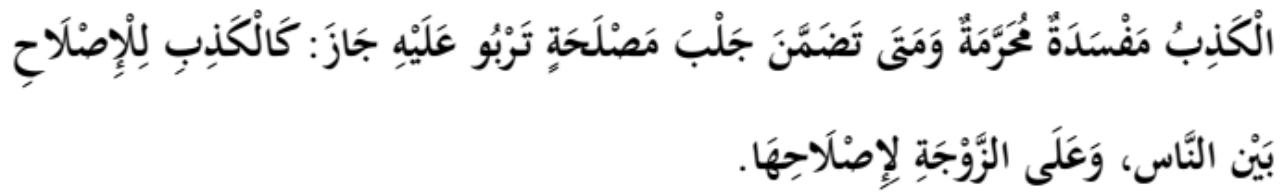

Artinya : bohong itu adalah merusak dan haram namun ketika ada unsur manfaat dan keberuntungan terhadap bohong itu dibolehkan seperti berbohong untuk mendamaikan orang dan berbohong untuk mendamaikan pasangan suami istri.

Adapun letak dua mafsadah/kerusakannya adalah berbohong itu haram, termasuk bohong untuk mendamaikan orang dan suami istri, namun bohong untuk mendamaikan dinilai mudharatanya lebih kecil walaupun termasuk dalam kategori mafsadah/kerusakan.

${ }^{15}$ Mustafa Ahmad Zarqa, al-Fiqh al-Islami fi Tsaubih al-Jadid (Beirut : Dar al-Fikr, 1965), jil 1, h. 114 .

${ }^{16}$ Suyuti, Nazair, h. 88. 
Contoh yang langsung diungkap oleh Imam Suyuti dalam masalah perceraian adalah kaidah dasar dari kaidah di atas yaitu :

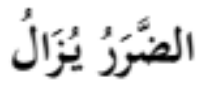

"Kemudharatan (bahaya/kerusakan) itu harus dihilangkan/dihindari)"

Imam Suyuti mencontohkan dengan :

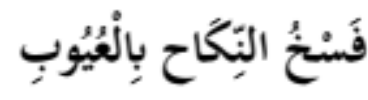

"Fasakh (putus/rusak) nikah karena memiliki aib".

Kaidah induk ini nampaknya lebih tepat untuk dirujuk dalam kasus cerai gugat, karena memang Imam suyuti langsug memberikan contoh dalam kasus yang rinci dalam putusnya pernikahan. Selain itu juga masalah perceraian dalam bab fikih merupakan bab-bab tertentu dari bidang hukum islam sehingga kaidah "Kemudharatan (bahaya/kerusakan) itu harus dihilangkan/dihindari)" lebih sesuai kaidah :

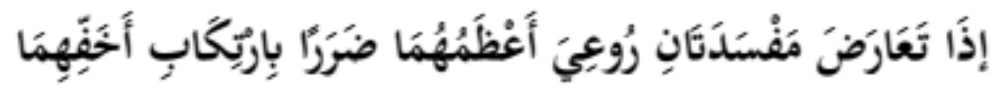

"Apabila berhadapan dua mafsadah dihindari mafsadah yang paling besar kemudratannya dengan melakukan yang lebih ringan mafsadahnya dapat juga digunakan dalam kasus cerai gugat hanya saja kaidah ini tidak berdiri sendiri, ada baiknya mencantumkan kaidah :

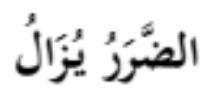

"Kemudharatan (bahaya/kerusakan) itu harus dihilangkan/dihindari)", kemudian kaidah tersebut dicantumkan.

Adanya Kaidah Lain Yang Dapat Digunakan Dalam Putusan Hakim Baik Dalam Masalah Perceraian Maupun Perkara Yang Lain

Dua Putusan Hakim yaitu Putusan Pengadilan Agama Medan Nomor 2192/Pdt.G/2019/PA.Mdn dan Nomor 2337/Pdt.G/2019/PA.Mdn di atas hanya membatasi pada kaidah yang membahas tentang kemudaratan, padahal masih ada kaidah-kaidah lain yang dapat dijadikan rujukan sebagai kaidah fikih yang dapat memutuskan perkara seperti kaidah :

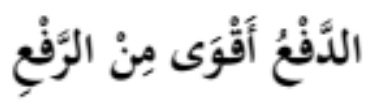

\section{"Mencegah lebih baik dari mengangkat/melakukan".}

Kaidah ini dapat diterapkan dalam memutuskan perkara cerai di mana jika pasangan suami istri masih terus bertahan dalam pernikahan justru akan menimbulkan bahaya yang besar, bahaya yang besar itu harus dicegah dari pada mempertahankan pernikahan, dalam hal ini menggunakan kaidah kaidah fikih yang jumlahnya sangat banyak serta tidak membatasinya penting karena melihat 
kompleksnya perkara umat Islam di Pengadilan Agama maka ahli fikih menawarkan kaidah-kaidah fikih yang dapat dijadikan penguat hukum.

Selain itu, Putusan Hakim hanya menggunakan kaidah fikih dalam mazhab Syafi'i, di luar mazhab Syafi'i masih ada kaidah-kaidah fikih yang lain yang dapat diterapkan dalam pertimbangan hukum diantaranya kaidah dalam mazhab Imam Ahmad bin Hanbal ${ }^{17}$ :

Contoh fur-' dari kaidah di atas yaitu seseorang gugur mempertahankan

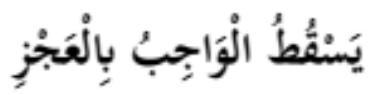

"Perbuatan wajib dapat gugur disebabkan ketidakmampuan".

pernikahannya karena pasangannya terlibat narkoba atau tidak memberikan nafkah rumah tangga.

Dalam mazhab lain yaitu mazhab Maliki ada kaidah fikih yang juga terkait dengan perkara ini yaitu ${ }^{18}$ :

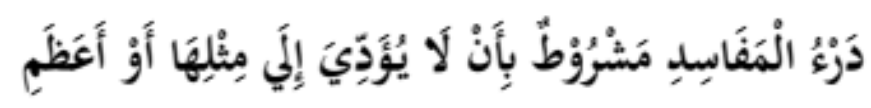

"Mencegah kerusakan itu disyaratkan agar tidak menyebabkan kepada kerusakan yang serupa atau kerusakan yang lebih besar".

Pada hakikatnya kaidah ini sama dengan kaidah

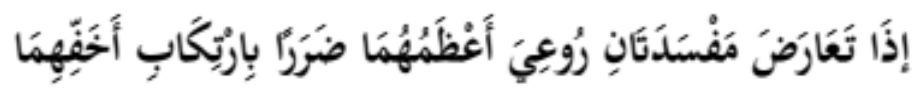

"Apabila berhadapan dua mafsadah dihindari mafsadah yang paling besar kemudratannya dengan melakukan yang lebih ringan mafsadahnya. (Asbahwa annazair, halaman 161);"

Dan kaidah

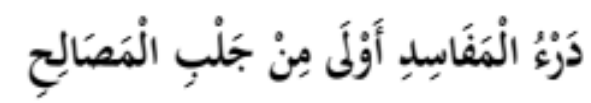

"menolak kerusakan lebih utama dari pada memilih kemaslahatan".

Untuk menambah khazanah hukum Islam, sebenarnya sangat banyak sekali kaidah-kaidah fikih warisan ulama, dengan adanya kaidah-kaidah fikih dalam bidang-bidang hukum tertentu akan mempermudah kita dalam memecahkan masalah yang dihadapi. Apabila masalahnya dalam bidang pernikahan maka carilah kaidah-kaidah fikih dalam bidang pernikahan, apabila tidak ditemukan maka ditelusuri kaidah-kaidah umum yang terkait masalah yang akan dikaji.

2. Kaidah yang digunakan dalam putusan gugat cerai sebelum ada Undang-

Undang Nomor 7 Tahun 1989 Tentang Peradilan Agama

Dalam Perkara Nomor 457/PTS/1988/PA.MDN, hakim tidak menggunakan kaidah fikih yang berbunyi :

\footnotetext{
${ }^{17}$ Ibnu Qadhi al-Jabal, Al-Qawā'id al-Fiqhiyyah (Beirut : Dar al-Fikr, t.t.), h. 252.

18 al-Maqqari al-Maliki, Al-Qawā‘id(Beirut : Dar al-Fikr, 1998.), h. 232.
} 


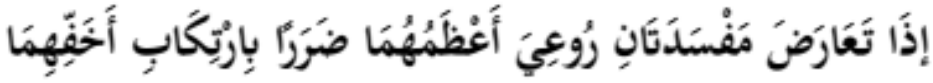

"Apabila berhadapan dua mafsadah dihindari mafsadah yang paling besar kemudratannya dengan melakukan yang lebih ringan mafsadahnya. (Asbahwa annazair, halaman 161);"

dalam pertimbangan hakim memutuskan perkara cerai gugat tersebut tetapi menggunakan dalil dari Kitab "Syarhut Tahrir" Juz-II, halaman 289, yang berbunyi sebagai berikut:

\section{من علق طلا قا بصفة و قع بوجو د ها عملا بمقتض اللفظ}

Artinya "Barang siapa yang menggantungkan Thalaqnya dengan suatu sifat, maka jatuhlah Thalaq tersebut dengan terwujudnya sifat dimaksud, semata-mata memandang kepada zahirnya lafaz Tha'liq Thalaq yang diucapkannya”

\section{E. Kesimpulan}

Dari berbagai macam ulasan di atas bahwa kaidah yang sering muncul dalam pertimbangan hakim memutuskan perkara cerai gugat adalah kaidah :

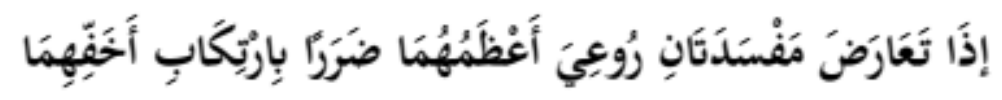

"Apabila berhadapan dua mafsadah dihindari mafsadah yang paling besar kemudratannya dengan melakukan yang lebih ringan mafsadahnya. (Asbahwa annazair, halaman 161);"

kaidah fikih di atas "Apabila berhadapan dua mafsadah dihindari mafsadah yang paling besar kemudratannya dengan melakukan yang lebih ringan mafsadahnya" ditinjau dalam ruang lingkup hukum pidana umum kaidah ini sesuai maknanya dengan asas in dubio proreo "jika ada keragu-raguan mengenai sesuatu hal haruslah diputuskan hal-hal yang menguntungkan terdakwa".

Yang kedua adalah kaidah fikih :

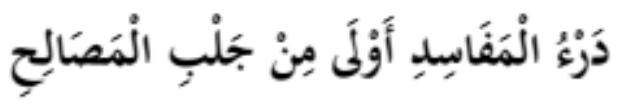

"menolak kerusakan lebih utama dari pada memilih kemaslahatan"

Pengunaan kaidah fikih oleh Hakim dalam memutuskan perkara mengetahui dan memahami kasusnya dengan menggunakan prinsip penalaran. Melihat dari sisi kemaslahatannya dan menghindari kemafsadatannya. Mafsadatnya dalam perkara ini adalah keburukan sebab sering terjadi selisih paham yang berujung pada percekcokan antara Penggugat dan Tergugat sehingga jalan yang ditempuh untuk kasus ini adalah perceraian. 
Masih ada kaidah-kaidah lain yang dapat dijadikan rujukan sebagai kaidah fikih yang dapat memutuskan perkara seperti kaidah :

$$
\text { الدَّفْعُ أَقْوَى مِنْ الرَّفْعِ }
$$

"Mencegah lebih baik dari mengangkat/melakukan".

Kaidah ini dapat diterapkan dalam memutuskan perkara cerai di mana jika pasangan suami istri masih terus bertahan dalam pernikahan justru akan menimbulkan bahaya yang besar, bahaya yang besar itu harus dicegah dari pada mempertahankan pernikahan, dalam hal ini menggunakan kaidah kaidah fikih yang jumlahnya sangat banyak serta tidak membatasinya penting karena melihat kompleksnya perkara umat Islam di Pengadilan Agama maka ahli fikih menawarkan kaidah-kaidah fikih yang dapat dijadikan penguat hukum.

Selain itu, Putusan Hakim hanya menggunakan kaidah fikih dalam mazhab Syafi'i, di luar mazhab Syafi'i masih ada kaidah-kaidah fikih yang lain yang dapat diterapkan dalam pertimbangan hukum diantaranya kaidah dalam mazhab Imam Ahmad bin Hanbal ${ }^{19}$ :

$$
\text { يَسنقُطُطُ الْوَاجِبُ بِالْفَجْز }
$$

"Perbuatan wajib dapat gugur disebabkan ketidakmampuan".

Contoh fur-' dari kaidah di atas yaitu seseorang gugur mempertahankan pernikahannya karena pasangannya terlibat narkoba atau tidak memberikan nafkah rumah tangga.

Dalam mazhab lain yaitu mazhab Maliki ada kaidah fikih yang juga terkait dengan perkara ini yaitu ${ }^{20}$ :

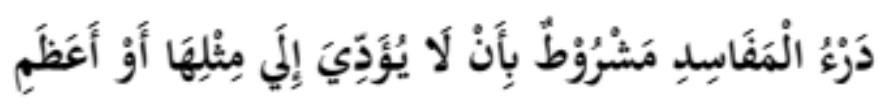

"Mencegah kerusakan itu disyaratkan agar tidak menyebabkan kepada kerusakan yang serupa atau kerusakan yang lebih besar".

Sebelum ada Undang-Undang Nomor 7 Tahun 1989 Tentang Peradilan Agama, hakim dalam pertimbangan memutus cerai gugat tidak mencantumkan kaidah fikih

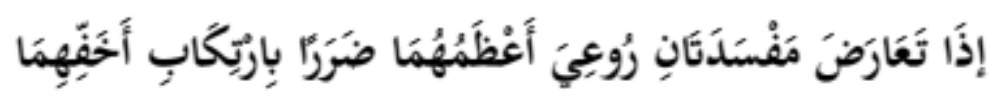

\footnotetext{
${ }^{19}$ Ibnu Qadhi al-Jabal, Al-Qawāid al-Fiqhiyyah (Beirut : Dar al-Fikr, t.t.), h. 252.
}

${ }^{20}$ al-Maqqari al-Maliki, Al-Qawāid (Beirut : Dar al-Fikr, 1998.), h. 232. 


\section{F. Daftar Pustaka}

Abd al-Baqi, Muhammad Fuad. 1990. Al-Mu'jam al-Mufahras li-alfaz al-Quran alKarim, Kairo : Dar al-Hadis.

Abdullah bin Abdul Muhsin Al-Turki. 1996. Ushulu Mazhab Imam Ahmad, Berut : Muassah Risalah.

Al-Dzhahabi. 1406 H/1986 M. Siyar A'alami al-Nubala. Berut : Muassasah Risalah.

Al-Ghazali, Imam. 1997. Al-Mustashfa Min Ilmi Al-Ushul. Berut : Muassasah Risalah.

Al-Juwaini, Imam Haramain. 1997. Al-Burhan Fii Ushul Fiqh, Berut : Darul Kutub Ilmiah.

Hammam. 2017. Urgensi Kaidah Fiqhiyyah Dalam Perumusan Hukum dan Implementasinya Dalam Fatwa DSN-MUI, Et-Tijarie: Jurnal Volume : 4, Nomor : 1.

Hassan, Husain Hamid. 1981. Nazhariah Al-Maslahah fi Al-Fiqhi Al-Islami, Kairo: Al-Mutanabbi.

Khallaf, Abdul Wahhab. 2003. Imu Ushul Figh. Jakarta : Pustaka Amani.

Luhuringbudi, Teguh dan Achmad Yani. 2018. Kaidah Fighiyyah Terhadap Perbedaan Pendapar Dalam Figih (Kasus Hukaman Tindak Pidana Konupsi), Al Izzah: Jumal Hasil-Hasil Penelitian-ISSN: 1978-9726 (p); 2541-0717 (e) Volume : 13. Nomor : 1 .

Muhammad, Majduddin bin Ya'qub Al-Fairu Zabadi. 1987. Al-Kanus Al-Muhith. Berut : Muassasah Risalah.

Muhammad, Rusydi Ali dan Yulmina. 2019. Multi Alasan Cerai Gugar: Tinjauan Fikih terhadap Cenai Gugat Perkara Nomor:013S/Pat.G/2015/MMS.Bna pada Mahkamah Syar'tyah Bandia Aceh, Samarah: Jumal Hulaum Keluarga dan Hulaum Islam Volume : 3 . Nomor : 1 .

Munawaroh, Lathifah. 2017. Penggınaan Kaidah Fiqhiyyah "Al-KhurijiMin AlKhiläf Mustahab" Terkait Bab Ibadah Dalam Kîtab I'änat AlThälibinn, Nuansa : Jurnal Volume : 14 , Nomor : 1 .

Muqorobin, Masybudi. 2007. Kaidah Fiqhijyah Sebagai Landasan Perilaku Ekonami Umat Islam: Suatu Kajian Teoritik, Jurnal Ekonomi dan Studi Pembangunan Volume : 8, Nomor: 2 .

Nasurion, Lahnmddin 2001. Pembaharnan Hukum Islam Dalam Mazhab Syafei. Bandung : Rosdakarya.

Qudamah, Ibnu 1997. Raudhah al-Nazhir Wa Jannatu al-Manazhir.Riyadh : Maktabah Rusd.

Syarifuddin, Amir. 2001. Ushul Figh 2 Jakarta : PT Logos Wacana Ilmu.

Yuslem, Nawir, 2007. Kitab Indik Ushul Fiqh konsep Mashlahah Imam Haramain Al-Juwaini. Bandung : Citapustaka.

Zulkifli, Suhaila. Putusmua Perkaninan Akibat Suami Menikah Tanpa Izin Dari Istri, Jurnal Hulkum Kaidah Media Konumikasi dan Informasi Hukum dan Masyarakat Volume : 18 . Nomor : 3 
Firmansyah, Heri. Qawaid Fiqhiyyah dalam Fatwa Majelis Ulama Indonesia. al-qadha, 2019, 6.2: 1-11. 